\title{
THE EFFECT OF PH ON THE FILTRATION, REABSORPTION, AND EXCRETION OF PROTEIN BY THE RAT KIDNEY *
}

\author{
By KENNETH D. GARDNER, JR. $\dagger$ \\ (From the Chemical Section, Department of Medicine, School of Medicine, University of \\ Pennsylvania, Philadelphia, Pa.)
}

(Submitted for publication July 26, 1960 ; accepted October 31, 1960)

In a paper discussing the protein content and acidity of human urine, von Hoesslin in 1909 suggested that a direct relationship existed between the hydrogen ion content and the protein content of human urine (1). Since then clinicians occasionally have commented on this relationship, some to confirm its existence $(2,3)$ and at least one to deny it (4). These comments usually have been based on the observation of patients thought to have proteinuria of the "benign" or "physiological" variety-e.g., orthostatic albuminuria. The present investigation was undertaken when a review of the pertinent publications since 1909 failed to reveal any formal laboratory study of the effect of $\mathrm{pH}$ on protein metabolism in the kidney. The study was designed to provide at least partial answers to two major questions. First, in mammals, do changes in the rate of urinary protein excretion accompany variations in the systemic and urinary hydrogen ion concentrations? Second, if such changes do occur, are they the result of changes in the filtration and/or reabsorption of protein within the kidney?

In these experiments the adult male rat was selected to represent the mammalian order, since rat urine is known to contain significant amounts of protein under normal conditions (5). In addition, the use of a laboratory animal afforded ready access to renal tissue in which the formation of "protein absorption droplets" (6) within the cells of the proximal convoluted tubules could be studied histologically.

The results of this investigation show that significant changes in urinary protein excretion accompany systemic acid-base disturbances in the male rat and suggest that this phenomenon is the

\footnotetext{
* Supported by a grant from the Heart Association of Southeastern Pennsylvania. Portions of this work have appeared in abstract form (Clin. Res. 1960, 8, 228).

†Daland Fellow of the American Philosophical Society.
}

result of changes in protein filtration at the glomerular level.

\section{MATERIALS AND METHODS}

General experimental conditions. Male Wistar rats weighing 185 to $213 \mathrm{~g}$ were housed in individual metabolic cages. They were fed Purina Dog Chow pellets for at least 24 hours preceding each experimental period. During urine collection periods solid food was withdrawn to minimize contamination of the urine by food particles, and the animals were given a solution of 15 per cent glucose in distilled water, thus insuring adequate volumes (7) of relatively clean urine. The urines were collected from screened funnels beneath each cage over periods of time ranging from 8 to 24 hours. Toluene and mineral oil were not routinely used in the collection containers, since preliminary observations indicated that only minimal urinary $\mathrm{pH}$ changes took place in the absence of these preservatives. These urines provided a control baseline against which the urines from subsequent experiments were compared. Variations in the systemic and urinary $\mathrm{pH}$ 's of these and additional animals were produced by the addition of 1 per cent $\mathrm{NH}_{4} \mathrm{Cl}, 5$ per cent $\mathrm{NaHCO}_{3}, 0.5$ per cent $\left(\mathrm{NH}_{4}\right)_{2} \mathrm{CO}_{3}$, or 0.04 per cent acetazolamide (Diamox ${ }^{1}$ ) to the 15 per cent glucose in their drinking water. While the animals drank their assigned solutions, urines were again collected over a time interval equal in length to the previously established control period.

Analysis of urinary $p H$ and protein excretion. Urinary volumes for each period were measured. Urinary and serum $\mathrm{pH}$ values were determined with a glass electrode $\mathrm{pH}$ meter within 1 hour after the collection terminated.

The Shevky-Stafford method (8) was chosen for routine use in determining the urinary protein concentration. This procedure consists of the addition of 2.5 $\mathrm{ml}$ of Tsuchyia's phosphotungstic acid reagent to a $4 \mathrm{ml}$ aliquot of the supernatant from the centrifuged urine specimen to be analyzed. The resultant precipitate is allowed to flocculate undisturbed for 1 minute and is then centrifuged at a constant speed at room temperature for 5 minutes in a centrifuge tube designed for this procedure. At the end of this time, the volume of the protein precipitate is read directly from a scale etched

\footnotetext{
${ }^{1}$ Kindly provided by the American Cyanamid Company, New York, N. Y.
} 


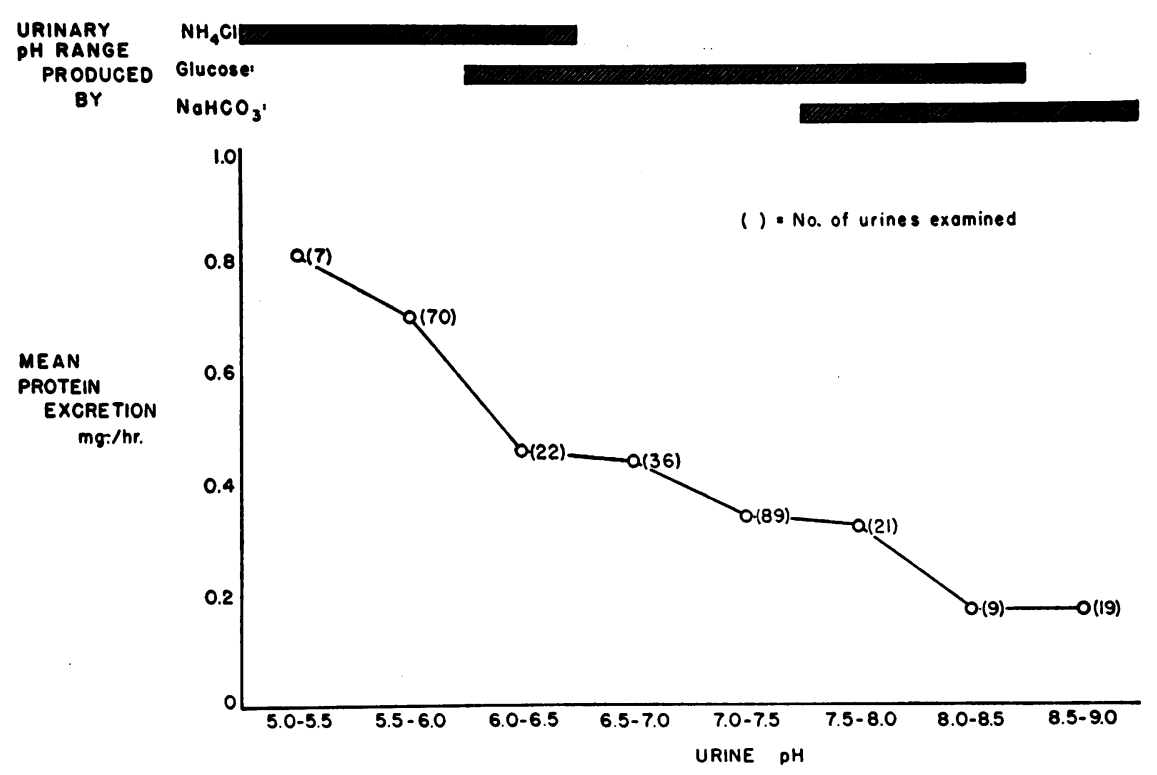

Fig. 1. The mean rates of URINARy protein excretion in 273 urines of 100

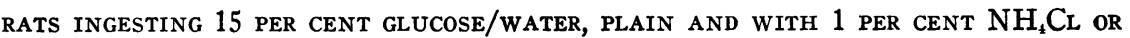
5 PER CENT $\mathrm{NAHCO}_{3}$ ADDED.

on each tube. This value is then used to determine the protein concentration of the specimen in milligrams per milliliter from a nomogram available for this purpose (9). The values obtained by this method agree closely with those obtained by the Kjeldahl procedure. Shevky and Stafford reported an average percentage error of 8.4 per cent in protein concentration of 30 specimens analyzed by both methods (8). A similar comparison among 10 specimens analyzed by both methods in our laboratory showed that the Shevky-Stafford method yielded results $4.4 \pm 3$ per cent higher than those obtained by the Kjeldahl procedure.

Random samples of individual rat serum and pooled urine specimens from animals partaking of each drinking solution were subjected to electrophoresis, using a barbital buffer at $\mathrm{pH}$ 8.6. Additional rats from each group were lightly anesthetized with ether and exsanguinated from the abdominal aorta in order to obtain blood for $\mathrm{pH}$ and serum for total $\mathrm{CO}_{2}$ content.

Observation of the "protein absorption droplet." It is known that protein undergoing reabsorption in the proximal portion of the mammalian nephron can appear within the proximal convoluted tubule (PCT) cells in the form of droplets (6). Various methods have been employed for their demonstration, and of these the one using T-1824 2 (Evans blue dye) as a serum protein label (10) was selected for this study. The protein absorption droplet, when formed from this dyed protein, can be seen microscopically within the PCT cells of unstained renal tissue.

2 Kindly supplied as W 761-1 by the Warner-Chilcott Laboratories, N. Y.
Rats were injected intravenously with $10 \mathrm{mg}$ of $\mathrm{T}-1824$ and were then allowed to drink ad libitum one of the above-mentioned drinking solutions for a period of $24 \pm$ 6 hours; during this time no solid food was furnished. After this the animals were sacrificed by exsanguination from the abdominal aorta, the kidneys removed, and frozen sections from these organs prepared and examined under the ordinary light microscope. In addition, the kidneys from a few rats which were not injected with the dye were prepared in a similar fashion and the sections examined either with the phase microscope or after Gram staining, these methods representing alternate ways by which the protein droplets can be demonstrated. Ten or more kidneys from rats drinking each of the various solutions were examined, and the size, number and distribution of the protein absorption droplets were observed.

\section{RESULTS}

Consistent and striking variations were observed in both urinary protein excretion rates and protein absorption droplet formation in these experiments. In general, protein excretion was higher in the more acid urines and lower in the more alkaline urines, as is shown in Figure 1. The data are given in Tables I and II; and the experimental results are presented in detail as follows.

Proteinuria and droplet formation in rats ingesting plain 15 per cent glucose and water. Un- 
der normal conditions the male rat excretes about $0.7 \mathrm{ml}$ per hour of urine containing $0.5 \mathrm{mg}$ of protein (5). In this study, the mean hourly urinary volume was increased to $2.6 \mathrm{ml}$ per hour by the addition of 15 per cent glucose to the drinking water (7). In the 76 urines from the 37 rats in this group, urinary protein excretion averaged $0.40 \mathrm{mg}$ per hour, with a mean urinary $\mathrm{pH}$ of 7.23. In random samples of arterial blood the $\mathrm{pH}$ averaged 7.41 and the total serum $\mathrm{CO}_{2}$ content, 22.6 mmoles per $\mathrm{L}$. These results were taken as "baseline" values for comparison with the results obtained in the remaining groups of rats.

Figure 2A shows the usual degree of protein absorption droplet formation that was observed in the kidneys from rats of this glucose-and-waterfed group; the degree of this droplet formation served as a baseline for comparison with the remaining groups. Electrophoresis of the urinary proteins present in this urine revealed all serum protein fractions to be represented except for albumin.

Proteinuria and droplet formation during $\left(\mathrm{NH}_{4}\right)_{2} \mathrm{CO}_{3}$ ingestion. In 40 specimens from 26 rats in this group, the urinary volume averaged $3.1 \mathrm{ml}$ per hour; urinary protein excretion, $0.36 \pm$ $0.03 \mathrm{mg}$ per hour; and urinary $\mathrm{pH}, 7.20$. Only the volume was significantly increased when compared with the glucose group. Neither blood $\mathrm{pH}$ nor total serum $\mathrm{CO}_{2}$ content was appreciably different. Droplet formation was identical with that in the control group.

Proteinuria and droplet formation during 1 per cent $\mathrm{NH}_{4} \mathrm{Cl}$ ingestion. In 69 specimens from 58 rats receiving 1 per cent $\mathrm{NH}_{4} \mathrm{Cl}$ in 15 per cent
TABLE I

Changes in urinary protein excretion rates in relation to urinary volume and $p H$

\begin{tabular}{|c|c|c|c|c|c|}
\hline \multirow[t]{2}{*}{ Regimen } & \multirow[t]{2}{*}{$\begin{array}{l}\text { No. } \\
\text { of rats }\end{array}$} & \multirow[t]{2}{*}{$\begin{array}{l}\text { No. of } \\
\text { speci- } \\
\text { mens }\end{array}$} & \multicolumn{2}{|c|}{$\begin{array}{l}\text { Mean urine } \\
\text { vol. } \mathrm{pH}\end{array}$} & \multirow{3}{*}{$\begin{array}{c}\begin{array}{c}\text { Mean pro- } \\
\text { tein excre- } \\
\text { tion rates }\end{array} \\
\boldsymbol{m g} / \boldsymbol{h r} \\
0.40 \pm 0.03^{*}\end{array}$} \\
\hline & & & $m l / h r$ & units & \\
\hline $\begin{array}{l}15 \% \text { Glucose/water } \\
\text { (controls) }\end{array}$ & 37 & 76 & 2.6 & 7.23 & \\
\hline $0.5 \%\left(\mathrm{NH}_{4}\right)_{2} \mathrm{CO}_{3}$ & 26 & 40 & 3.1 & 7.20 & $0.36 \pm 0.03$ \\
\hline $1 \% \mathrm{NH}_{4} \mathrm{Cl}$ & 58 & 69 & 1.0 & 5.68 & $0.75 \pm 0.04$ \\
\hline $5 \% \mathrm{NaHCO}_{3}$ & 12 & 20 & 3.2 & 8.02 & $0.17 \pm 0.04$ \\
\hline $0.04 \%$ Acetazolamide & 38 & 42 & 1.6 & 7.51 & $0.40 \pm 0.05$ \\
\hline
\end{tabular}

* $\mathrm{SE}=$ standard error of the mean.

glucose and water, the urinary volume averaged $1.0 \mathrm{ml}$ per hour; urinary protein excretion was increased to $0.75 \pm 0.04 \mathrm{mg}$ per hour. This rate was significantly different from that in the control group $(p<0.005)$. In the acid-fed rats the urinary $\mathrm{pH}$ was 5.68 (also significantly different), and determinations of $\mathrm{pH}$ and total serum $\mathrm{CO}_{2}$ content on random blood samples averaged 7.28 and 14.9 mmoles per L, respectively. Accompanying this acidosis and increased proteinuria was a pronounced increase in the degree of PCT cell droplet formation (Figure 2B). Electrophoresis of urine from these rats disclosed small amounts of albumin and a 700 per cent increase in the $\alpha$-globulin fraction over that noted in the glucose controls.

The reversibility of this $\mathrm{NH}_{4} \mathrm{Cl}$-induced proteinuria was demonstrated by alternating a group of four rats every 48 hours between the $\mathrm{NH}_{4} \mathrm{Cl}$ and the $\left(\mathrm{NH}_{4}\right)_{2} \mathrm{CO}_{3}$ drinking solutions for a 20 day period. Proteinuria rose during $\mathrm{NH}_{4} \mathrm{Cl}$ in-

TABLE II

Protein absorption droplet formation in relation to blood $p H$, urinary $p H$, and urinary protein excretion

\begin{tabular}{|c|c|c|c|c|c|}
\hline Regimen & $\begin{array}{l}\text { Mean total } \\
\text { serum CO } \mathrm{CO}_{2} \\
\text { content* }\end{array}$ & Blood $\mathrm{pH}$ & Urine $\mathrm{pH}$ & $\begin{array}{l}\text { Urinary } \\
\text { protein } \\
\text { excretion }\end{array}$ & $\begin{array}{c}\text { Protein } \\
\text { droplet } \\
\text { formation }\end{array}$ \\
\hline $\begin{array}{l}15 \% \text { Glucose/water } \\
\text { (controls) }\end{array}$ & $\begin{array}{r}m \text { mole } / L \\
22.6[3]\end{array}$ & $7.41[4]$ & Normal & Normal & Normal \\
\hline $0.5 \%\left(\mathrm{NH}_{4}\right)_{2} \mathrm{CO}_{3}$ & $24.5[2]$ & $7.38[2]$ & Normal & Normal & Normal \\
\hline $1 \% \mathrm{NH}_{4} \mathrm{Cl}$ & $14.9[10]$ & $7.28[4]$ & Acid & Increased & Increased \\
\hline $5 \% \mathrm{NaHCO}_{3}$ & $33.3[6]$ & $7.58[4]$ & Alkaline & Decreased & $\begin{array}{l}\text { Decreased } \\
\text { to absent }\end{array}$ \\
\hline $0.04 \%$ Acetazolamide & $15.6[14]$ & $7.32[4]$ & $\begin{array}{l}\text { Slightly } \\
\text { alkaline }\end{array}$ & Normal & Increased \\
\hline
\end{tabular}

* Numbers in brackets indicate the number of animals studied. 
gestion and fell during $\left(\mathrm{NH}_{4}\right)_{2} \mathrm{CO}_{3}$ ingestion, as is shown in Figures 3 and 4 . There was a high negative correlation of urinary $\mathrm{pH}$ and protein excretion in this experiment $(\mathrm{R},-0.83, \mathrm{p}, 0.001)$.

Preliminary evidence suggesting that $\mathrm{NH}_{4} \mathrm{Cl}$
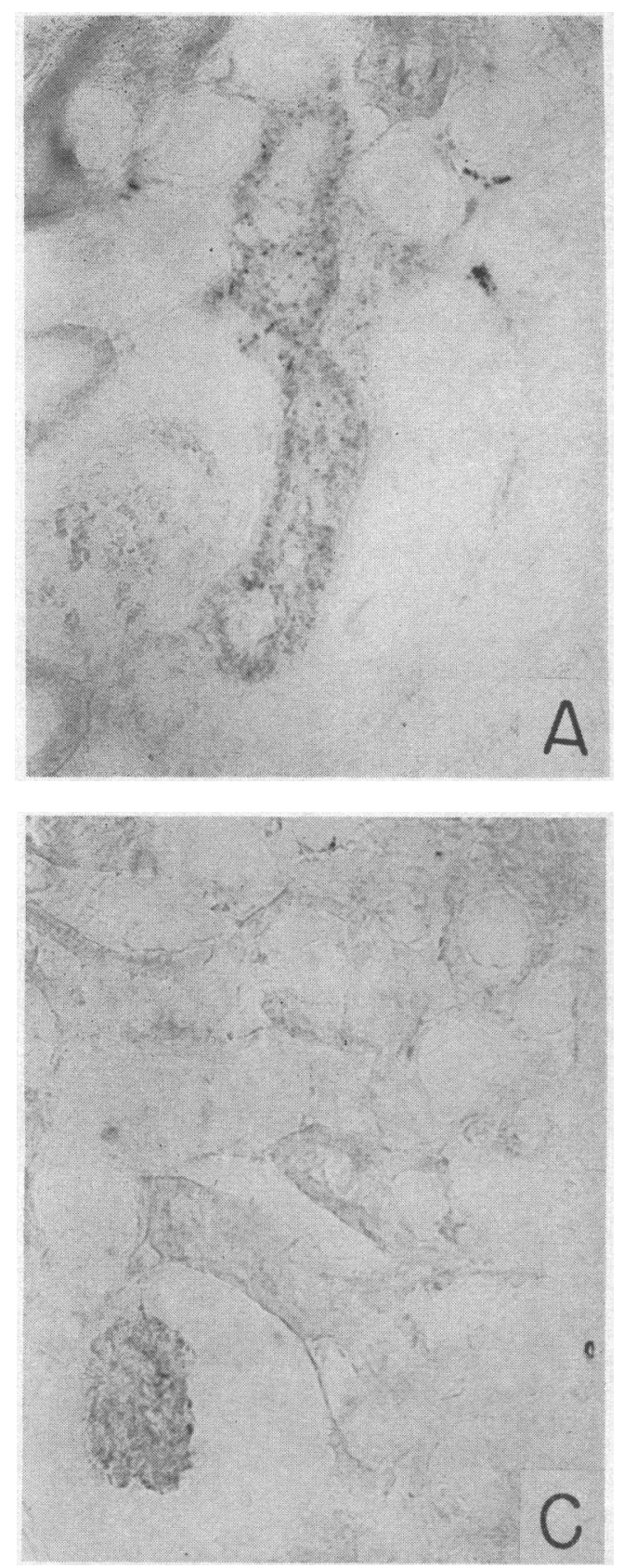

Fig. 2. Protein absorption droplets Within the proximal convoluted tUbUle cells of Rats inJeCted 24 hours EARLIER with T-1824. A, after 24 hours on 15 per cent glucose and water $(\times 385)$; B, after 24 hours on 1 per cent $\mathrm{NH}_{4} \mathrm{Cl}(\times 385)$; C, after 24 hours on 5 per cent $\mathrm{NaHCO}_{3}(\times 385)$; D, after 48 hours on 1 per cent $\mathrm{NH}_{4} \mathrm{Cl}$ but 24 hours after the injection of dye. may have the same effect on urinary protein excretion in man was found in the observation that two of four humans receiving $\mathrm{NH}_{4} \mathrm{Cl}$ for other purposes (11) experienced a threefold increase in their urinary protein excretion.
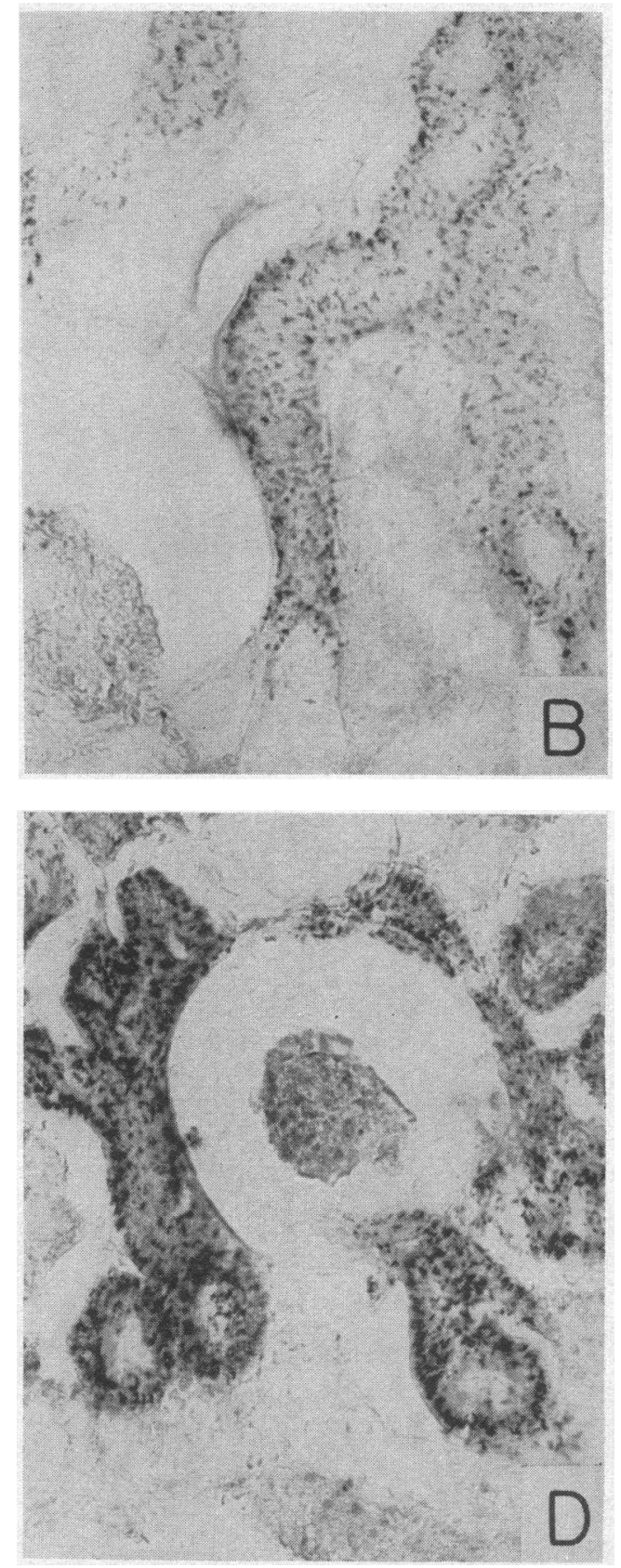

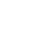


PH AND PROTEIN METABOLISM IN THE RAT KIDNEY

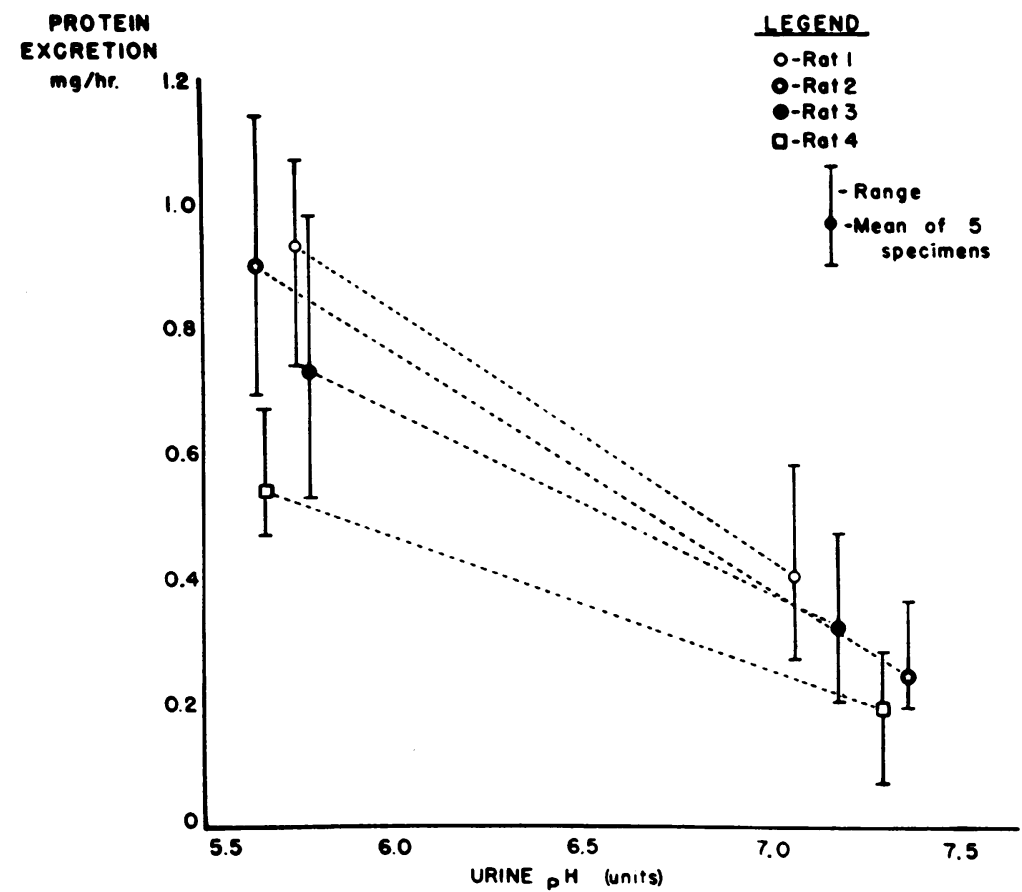

Fig. 3. MEAN URINARY PROTEIN EXCRETION RATES IN FOUR RATS ALterNATED BETWEEN 1 PER CENT $\mathrm{NH}_{4} \mathrm{CL}$ AND 0.5 PER CENT $\left(\mathrm{NH}_{4}\right)_{2} \mathrm{CO}_{3}$ EVERY 48 HOURS FOR 20 DAYS. Acid urines were obtained during $\mathrm{NH}_{4} \mathrm{Cl}$ ingestion only.

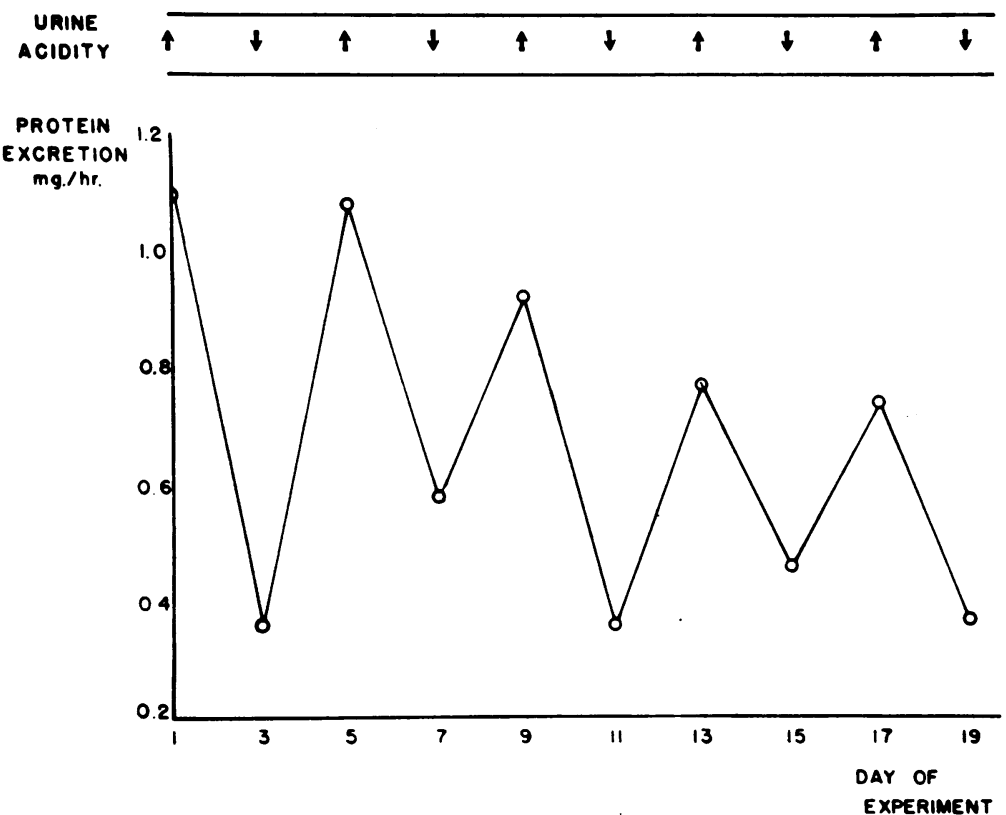

Fig. 4. AsSOCIATION OF INCREASED URINARY PROTEIN EXCRETION WITH INCREASED URINARY ACIDITY (LOWERED URINARY PH) IN RAT 1 OF FigURE 3 OVER A 19 DAY PERIOD. 


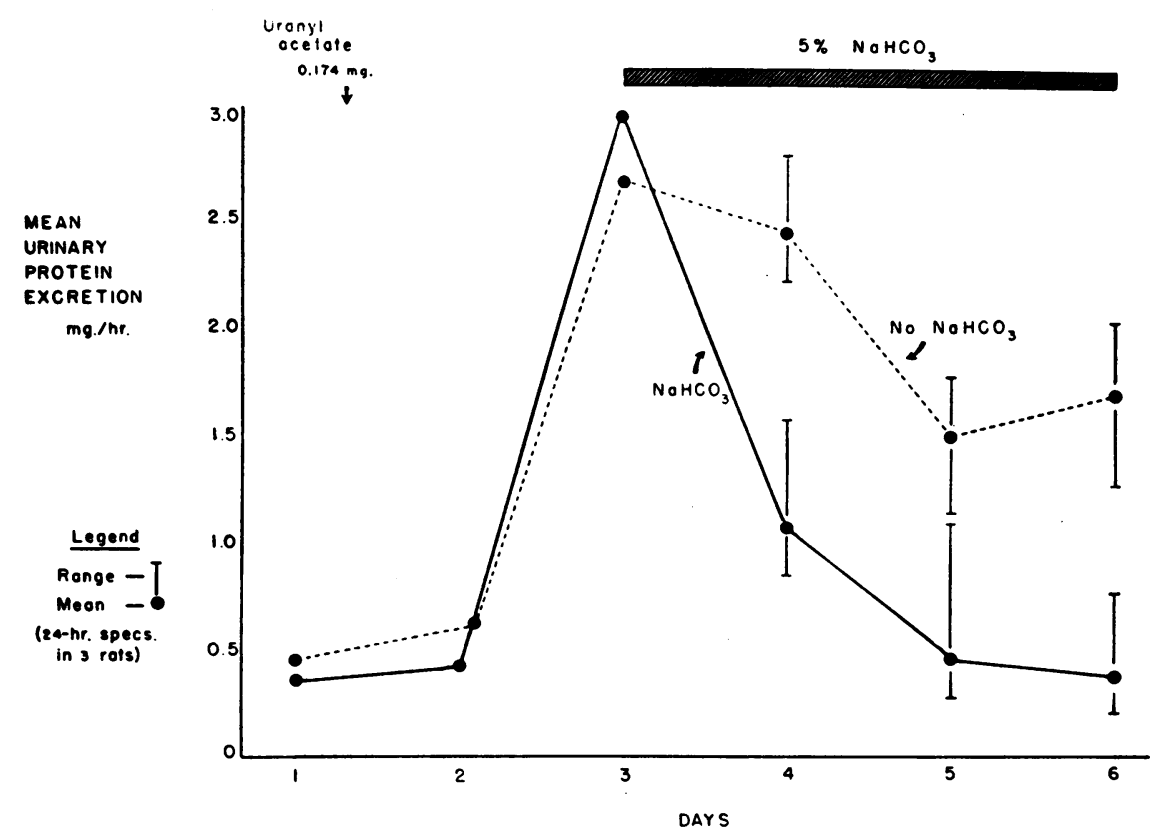

Fig. 5. EFFect of 5 PER CENT $\mathrm{NaHCO}_{3}$ ON THE RATES OF URINARY PRotein EXCRETION IN THREE RATS WITH PROXIMAL CONVOLUTED TUBULE CELlS DAMAGED BY URANYL ACETATE, COMPARED WITH THREE SIMILAR RATS GIVEN ONLY 15 PER CENT GLUCOSE/WATER.

Proteinuria and droplet formation during $\mathrm{Na}$ $\mathrm{HCO}_{3}$ ingestion. In 20 urine specimens from 12 rats ingesting the $\mathrm{NaHCO}_{3}$ in 15 per cent glucose solution, hourly urine volumes averaged 3.2 $\mathrm{ml}$. When compared with the glucose and water controls, the average hourly urinary protein excretion was decreased to $0.17 \pm 0.04 \mathrm{mg}$, with a mean urinary $\mathrm{pH}$ of 8.02 . The presence of a systemic alkalosis was confirmed by an average blood $\mathrm{pH}$ rise to 7.58 and a total serum $\mathrm{CO}_{2}$ content mean of 33.3 mmoles per L. Electrophoresis of the urinary protein in the group again disclosed the presence of small amounts of all serum fractions except albumin.

The decreased proteinuria accompanying $\mathrm{Na}$ $\mathrm{HCO}_{\text {; }}$ ingestion was associated with a virtually complete absence of protein absorption droplets within the kidneys of these rats (Figure 2C).

The observation that $\mathrm{NaHCO}_{3}$ ingestion significantly lowered the urinary excretion of "physiological" protein raised the question: What might its effect be on "pathological" proteinuria? In an attempt to answer it, the following experiment was performed.

After the collection of control urines, six rats were given an intravenous injection of $0.175 \mathrm{mg}$ of uranyl acetate, an amount known to damage severely the PCT cells of rats of similar size (12). Thirty-six hours later, 5 per cent $\mathrm{NaHCO}_{3}$ was added to the glucose drinking solution of three of the six rats. A prompt and significant fall in the rates of urinary protein excretion was observed in these rats, while in the three animals continued on plain glucose and water, increased proteinuria persisted (Figure 5).

Proteinuria and droplet formation in 0.04 per cent acetazolamide ingestion. In 42 urines from 38 rats receiving the acetazolamide-glucose solution, the mean urine volume was $1.6 \mathrm{ml}$ per hour. The mean urinary protein excretion did not differ from that observed in the plain glucose group, averaging $0.40 \pm 0.05 \mathrm{mg}$ per hour. However, the blood $\mathrm{pH}$ in these animals was reduced to 7.32 and the total serum $\mathrm{CO}_{2}$ content to 15.6 mmoles per L. Urinary protein electrophoresis yielded a pattern similar to that found in the control urines.

When acetazolamide was alternated every 48 hours with the $\mathrm{NH}_{4} \mathrm{Cl}$ solution, in one experiment, it neither produced nor maintained the increased proteinuria accompanying the ingestion of the 
$\mathrm{NH}_{4} \mathrm{Cl}$ solution (Figure 6). It did, however, produce and apparently maintain the acidemia.

\section{DISCUSSION}

The relationship between $p H$ and proteinuria. The results of these experiments in rats support the clinical observations made in humans that changes in $\mathrm{pH}$ are accompanied by alterations in the rates of urinary protein excretion. In the acidemia and aciduria of $\mathrm{NH}_{4} \mathrm{Cl}$ ingestion, urinary protein output was accelerated, and its prompt and repeated reversibility suggests that it was not the result of permanent damage to the kidney.

Consideration was given to other factors that might have influenced the excretion of urinary protein. Finlayson and Baumann (13) observed a direct correlation of urinary volume and protein content in male rats. In the present study, however, the highest rates of protein excretion occurred in association with the lowest average urinary volumes (the $\mathrm{NH}_{4} \mathrm{Cl}$-fed rats). Therefore, simple changes in volume did not seem to be responsible for the increased proteinuria. In the same report these authors also mentioned that ingestion of urea increased urinary protein excre- tion. In our experiments, however, it seemed not plausible to attribute the increased proteinuria accompanying $\mathrm{NH}_{4} \mathrm{Cl}$ ingestion to an excess of ammonium ion, if not urea, since the daily intake of that ion in rats receiving $\mathrm{NH}_{4} \mathrm{Cl}$ (with increased proteinuria) averaged $3.7 \mathrm{mEq}$ per day, while its intake in rats receiving $\left(\mathrm{NH}_{4}\right)_{2} \mathrm{CO}_{3}$ (without increased proteinuria) averaged 5.2 $\mathrm{mEq}$ per day. Nor was the chloride ion apparently responsible, since proteinuria did not increase in rats receiving chloride ions in the form of $\mathrm{KCl}$ or $\mathrm{NaCl}$ in the experiments described by Masson, del Greco, Corcoran and Page (14).

If, then, hydrogen ion concentration is the key to this observed phenomenon, where and how might it exert its effect? An answer was sought in the changes found in the formation of the protein absorption droplets in the various experimental groups.

The protein absorption droplet. Oliver and others have intensively studied the droplets which form within cells of the PCT during protein reabsorption. Working with Straus, he extracted the droplets from the PCT cells of rats injected with egg albumin and found that the amount of the protein within the droplets was higher than that in the remaining cellular substrate (15). From
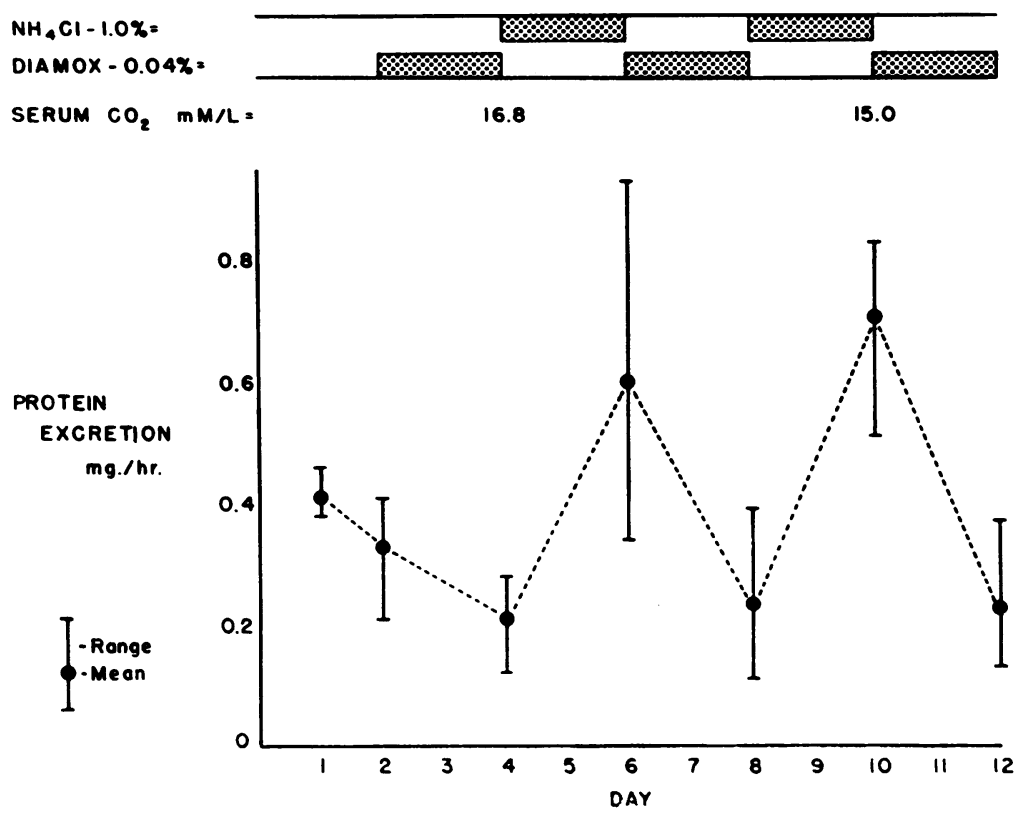

Fig. 6. Failure of acetazolamide ingestion to PRoduce or maintain INCREASED URINARY PROTEIN EXCRETION PRODUCED BY $\mathrm{NH}_{4} \mathrm{CL}_{L}$ INGESTION IN A GROUP OF THREE RATS. 
this and other studies Oliver has concluded that the protein absorption droplet represents an intracellular accumulation of protein, appearing whenever the normal mechanisms of cellular protein disposal are inadequate (6). This inadequacy may be the result of either an increased demand imposed on the cells by the reabsorption of increased amounts of protein or a deficiency in the ability of the cells to dispose of normal amounts of reabsorbed protein (6). From this it follows that a simple assessment of the size and number of these droplets in a given kidney does not permit any conclusion regarding the rate or the amount of protein undergoing reabsorption, unless further information is made available about the conditions under which the droplets were formed. In the present study, this information was sought in parallel experiments as the need arose and will be presented in abbreviated form when the significance of droplet formation in each of the experimental groups of rats is discussed below.

Suitability of T-1824 as a protein-absorption droplet indicator. The fact that $\mathrm{T}-1824$ can be found in droplet form within the PCT cells of animals which have been injected with the dye does not necessarily mean that protein reabsorbed from the glomerular filtrate is also present within the droplet, although the available evidence strongly suggests that this is the case. In vitro, $\mathrm{T}-1824$ has been shown to bind rapidly (within 50 seconds) to serum protein, primarily albumin (16), with a bond that is approximately three times as strong as the peptide linkages of the protein molecule itself (17). This union cannot be disrupted by incubating dye-labeled protein with liver slices (18). In vivo, the injection of T-1824 in doses up to 2.5 times greater than the amount used in these present studies does not result in the appearance of free dye in the serum (19) or in the urine (20); nor can dye be detected within the PCT cells immediately after its injection (19).

To test the possibility that $\mathrm{T}-1824$ might leave more readily the protein of the tubular fluid to enter absorption droplets that were already present, $10 \mathrm{mg}$ of T-1824 was injected intravenously into a series of rats 24 hours after the intraperitoneal injection of egg albumin. More than 7 and less than 24 hours elapsed before any droplets containing dye could be found in the kidneys of this group of serially-sacrificed rats, and even after 24 hours colored droplets were only sparsely scattered through their PCT cells. However, when these kidneys were examined with the Gram stain technique, a myriad of protein droplets was seen. These results imply that T-1824 is not freed from filtered protein at the cells' tubular border to enter the cell in the unbound state.

Interest in the $\mathrm{pH}$ changes occurring in these animals led to a study of the effect of $\mathrm{pH}$ on the ability of protein to bind T-1824 by means of in vitro use of bovine albumin solutions adjusted to pH's of 6.7 and 7.9. Eight moles of dye was added to each mole of protein present, a dye: protein ratio which closely approaches the saturation level for protein binding of dye at $\mathrm{pH} 7.4$ (21). Less than a 10 per cent difference was found, with slightly more dye being bound at the lower $\mathrm{pH}$, a difference considered insufficient to produce the degree of variation observed in droplet colorations in these present experiments. Therefore, from the evidence available, $\mathrm{T}-1824$ appeared to be a suitable indicator for the detection of protein absorption droplets in this study.

Droplet formation and its significance in the $\mathrm{NH}_{4} \mathrm{Cl}$ experiments. The addition of 1 per cent $\mathrm{NH}_{4} \mathrm{Cl}$ to a 15 per cent glucose drinking solution was found to increase the formation of protein absorption droplets within the rat kidney. Referring to Oliver's hypothesis mentioned above, this increase could signify either an increase in the amount of protein undergoing reabsorption or a decrease in the ability of the cells to dispose of the reabsorbed protein. An attempt was made to ascertain the ability of the PCT cells in rats to dispose of reabsorbed protein.

Examination, under the phase microscope, of renal sections from undyed rats showed that absorption droplets were increased after 24 hours of $\mathrm{NH}_{4} \mathrm{Cl}$ ingestion. If, at this point, rats were injected with T-1824 and maintained for a second 24-hour period on $\mathrm{NH}_{4} \mathrm{Cl}$, their kidneys were found to contain numerous, intensely colored protein droplets (Figure 2D). Under the phase microscope no droplets of undyed protein could be detected in other areas of the cytoplasm of these cells. The fact that droplet coloration in this experiment was greater than that observed in the kidneys from dyed rats after only 24 hours on $\mathrm{NH}_{4} \mathrm{Cl}$ made it difficult to assume that the dyed 
protein had entered and mixed with the undyed protein present within each droplet. It appeared that the undyed protein had been eliminated from the PCT cells to make way for the accumulation of the dyed protein, implying that these cells were able to continue protein disposal while under the influence of $\mathrm{NH}_{4} \mathrm{Cl}$.

Thus it seemed likely that the increased droplet formation within the kidneys of rats ingesting $\mathrm{NH}_{4} \mathrm{Cl}$ was the result of increased amounts of protein passing through the cells, and in this instance indicated increased protein reabsorption. Coupling this information with the observation that these animals were also excreting increased amounts of protein in their urines, the inference may be made that increased amounts of protein were being filtered at the glomerular membrane.

Droplet formation and its significance in the $\mathrm{NaHCO}_{3}$ experiments. Protein absorption droplets were very scarce or were completely absent in the kidneys from rats that had ingested $\mathrm{Na}$ $\mathrm{HCO}_{3}$, implying either decreased reabsorption of protein or accelerated disposal of protein by the cells. To distinguish between these two possibilities, the PCT cells of an additional group of rats were damaged by the injection of uranyl acetate. Sodium bicarbonate was still effective in reducing urinary protein excretion under these circumstances despite the cellular damage and the disruption of protein reabsorption mechanisms, as have been described in uranium nephritis by Goodman and Baxter (12). Since the action of $\mathrm{NaHCO}_{3}$ apparently is not dependent on the integrity of the PCT cells, it seems more likely that it reduced proteinuria in these experiments by reducing the amount of protein passing through the glomerular membrane. It was concluded that the decreased proteinuria of rats ingesting $\mathrm{NaHCO}_{3}$ was the result of diminished glomerular protein filtration. In the light of this conclusion, it is of interest to recall the clinical observations of Schultz and Collier (22), Fox and McCune (23), and others who have described remissions in the nephrotic syndromes of their patients following massive alkali loading.

Droplet formation and its significance during acetazolamide ingestion. Droplet formation in the PCT cells of rats ingesting acetazolamide was identical in all respects with that observed in the kidneys from animals ingesting $\mathrm{NH}_{4} \mathrm{Cl}$. Sys- temic acidosis was also present in both groups of animals. Yet the urinary excretion of protein was unchanged by acetazolamide ingestion. When acetazolamide instead of $\mathrm{NH}_{4} \mathrm{Cl}$ was furnished to rats for 24 hours before and for 24 hours after the injection of $\mathrm{T}-1824$, no droplets of undyed protein were found, and droplet coloration was intensified. This again suggested that there was no severe impairment in the ability of the cells to dispose of protein during acetazolamide ingestion. Thus, increased protein filtration was implicated. Since increased urinary protein excretion was not observed in these animals, the reabsorption of protein during acetazolamide ingestion may have been sufficient to compensate for the suspected increase in protein filtration. It is equally possible, on the other hand, that some other effect of acetazolamide counteracted the effect of its acidemia on the increased filtration of protein to maintain protein excretion at normal levels.

Since the primary purpose of this present study was to determine the effect on proteinuria of a simple acid or alkali load and since spontaneous impairment of carbonic anhydrase activity has not been described in mammals, further exploration of the effect of acetazolamide on renal protein metabolism was not performed at this time.

Localization of the hydrogen ion effect. The task of demonstrating an effect of hydrogen ion concentration on either the filtration or the reabsorption of protein within the rat kidney would have been considerably easier were it possible to measure the rates of these processes directly. In the absence of a more adequate method, it was necessary to approach the problem indirectly, using the degree of protein droplet formation in the variety of experimental circumstances described above. In both the $\mathrm{NH}_{4} \mathrm{Cl}$ and $\mathrm{NaHCO}_{3}$ groups of rats, the results of this approach suggested, more strongly than not, that the observed change in urinary protein excretion was primarily the result of a concomitant change in the rate of protein filtration at the glomerulus. The experiments did not delineate whether this is a direct effect of hydrogen ion on the glomerular membrane or an indirect effect on renal blood flow, on the physical or electrostatic configuration of the serum protein molecules, or on some other mechanism involved in protein filtration. 


\section{SUM MARY}

Changes in blood acidity and urinary $\mathrm{pH}$ were produced in rats by the ingestion of 1 per cent $\mathrm{NH}_{4} \mathrm{Cl}, 5$ per cent $\mathrm{NaHCO}_{3}$, and 0.04 per cent acetazolamide (Diamox) in a 15 per cent glucoseand-water drinking solution. The concomitant rate of urinary protein excretion was measured. During $\mathrm{NH}_{4} \mathrm{Cl}$ and $\mathrm{NaHCO}_{3}$ ingestion a negative correlation was found between urinary and serum $\mathrm{pH}$ and the degree of proteinuria. In general, the more acid the urine and the blood, the greater the proteinuria. The increased proteinuria observed during $\mathrm{NH}_{4} \mathrm{Cl}$ ingestion was promptly reversible when a neutral or alkaline drinking solution was substituted, and the urinary and systemic $\mathrm{pH}$ consequently was increased.

A study of protein absorption droplets within the proximal convoluted tubule cells of kidneys from each group of rats was made. An increase in droplet formation was observed in the presence of a lowered serum $\mathrm{pH}$. The observation that $\mathrm{T}$-1824-labeled protein replaced undyed protein in these droplets during established acidosis suggested continuing protein reabsorption during $\mathrm{NH}_{4} \mathrm{Cl}$ ingestion. This in turn suggested increased protein filtration as the primary cause for the increased proteinuria in these animals. A decrease in droplet formation was observed in the presence of an elevated serum $\mathrm{pH}$. The ability of $\mathrm{NaHCO}_{3}$ to reduce the proteinuria of uranium nephritis in rats suggested that tubular cell integrity was not essential for its action and that the decrease in proteinuria observed during alkalosis was not primarily the result of increased reabsorption but of decreased glomerular filtration.

These experiments demonstrate that the physiological proteinuria of the male rat varies with changes in the animal's acid-base equilibrium and suggest that this phenomenon is related primarily to concomitant changes in the filtration rather than to reabsorption of protein within its kidneys.

\section{ACKNOWLEDGMENTS}

The author would like to express his sincere appreciation to Drs. Jean Oliver, J. Russell Elkinton, Francis C. Wood, Lewis W. Bluemle, Howard M. Rawnsley and Joseph C. Handler for their aid in designing these experiments, in discussing the results, and in helping with the preparation of the manuscript.

\section{REFERENCES}

1. von Hoesslin, R. Über die Abhängigheit der Albuminurie vom Säuregehalt des Urins. Münch. med. Wschr. 1909, 56, 1673.

2. Post, W. E., and Thomas, W. A. Orthostatic albuminuria. J. Amer. med. Ass. 1923, 80, 293.

3. Berglund, H., and Medes, G., Eds. The kidney in health and disease in Contributions by Eminent Authorities. Philadelphia, Lea and Febiger, 1935, p. 469.

4. Fishberg, A. M. Hypertension and Nephritis, 5th ed. Philadelphia, Lea and Febiger, 1954, p. 406.

5. Sellers, A. L. The mechanism and significance of protein excretion by the normal kidney. A.M.A. Arch. intern. Med. 1956, 98, 801.

6. Oliver, J., and MacDowell, M. Cellular mechanisms of protein metabolism in the nephron. VII. The characteristics and significance of the protein absorption droplets (hyaline droplets) in epidemic hemorrhagic fever and other renal diseases. J. exp. Med. 1958, 107, 731.

7. Addis, T., Barrett, E., Boyd, R. I., and Ureen, H. J. Renin proteinuria in rat; I. Relation between proteinuria and pressor effect of renin. J. exp. Med. 1949, 89, 131.

8. Shevky, M. C., and Stafford, D. D. A clinical method for the estimation of protein in urine and other body fluids. Arch. intern. Med. 1932, 32, 222.

9. Lippman, R. W. Urine and the Urinary Sediment: A Practical Manual and Atlas. Springfield, Ill, Charles C Thomas, 1957, p. 107.

10. Gilson, S. B. Studies on proteinuria in the rat. Proc. Soc. exp. Biol. (N. Y.) 1949, 72, 608.

11. Elkinton, J. R., Huth, E. J., Webster, G. D., Jr., and McCance, R. A. The renal excretion of hydrogen ion in renal tubular acidosis. I. Quantitative assessment of the response to ammonium chloride as an acid load. Amer. J. Med. 1960, 29, 554.

12. Goodman, H. C., and Baxter, J. H. Tubular reabsorption of protein in experimentally produced proteinuria in rats. Proc. Soc. exp. Biol. (N. Y.) 1956, 93, 136.

13. Finlayson, J. S., and Baumann, C. A. Role of urea in rat proteinuria. Amer. J. Physiol. 1956, 184, 469.

14. Masson, G. M. C., del Greco, F., Corcoran, A. C., and Page, I. H. Factors influencing renin diuresis and proteinuria. Proc. Soc. exp. Biol. (N. Y.) 1953, 83, 631.

15. Straus, W., and Oliver, J. Cellular mechanisms of protein metabolism in the nephron. VI. The immunological demonstration of egg white in droplets and other cellular fractions of the rat kidney after intraperitoneal injection. J. exp. Med. 1955, $102,1$.

16. Barnes, D. W. H., Loutit, J. F., and Reeve, E. B. Observations on the estimate of the circulating 
red blood cell volume in man given by $\mathrm{T} 1824$ and the hematocrit, with special reference to uncorrected dye loss from the circulation. Clin. Sci. 1948, 7, 155.

17. Allen, T. H., and Orahovats, P. D. Combination of toluidine dye isomers with plasma albumin. Amer. J. Physiol. 1950, 161, 473.

18. Allen, T. H., and Orahovats, P. D. Kinetics of reaction between $\mathrm{T}-1824$ and liver slice in mixtures of plasma albumin. Amer. J. Physiol. 1951, 164, 123.

19. Mendel, D. Tubular reabsorption of protein in the rat. J. Physiol. (Lond.) 1959, 148, 1.
20. Sellers, A. L., Smith, S., III, Marmorston, J., and Goodman, H. C. Studies on the mechanism of experimental proteinuria. J. exp. Med. 1952, 96, 643.

21. Rawson, R. A. The binding of T-1824 and structurally related diazo dyes by the plasma proteins. Amer. J. Physiol. 1942, 138, 708.

22. Schultz, F. W., and Collier, J. L. The treatment of nephrosis. in the young child. J. Amer. med. Ass. 1937, 109, 1959.

23. Fox, C. L., Jr., and McCune, D. J. Electrolyte changes in nephrosis. Occurrence of diuresis following administration of sodium and potassium salts. Amer. J. med. Sci. 1948, 216, 1. 